\title{
Temperature Regulation of Photovoltaic Module Using Phase Change Material: A Numerical Analysis and Experimental Investigation
}

\author{
Hasan Mahamudul, ${ }^{1}$ Md. Momtazur Rahman, ${ }^{2}$ H. S. C. Metselaar, ${ }^{1}$ Saad Mekhilef, \\ S. A. Shezan, ${ }^{1}$ Rana Sohel, ${ }^{1}$ Sayuti Bin Abu Karim, ${ }^{1}$ and Wan Nur Izzati Badiuzaman ${ }^{1}$ \\ ${ }^{1}$ Faculty of Engineering, University of Malaya, Kuala Lumpur 50670, Malaysia \\ ${ }^{2}$ Institute of Micro and Nanomaterials, University of Ulm, Helmholtzstraße 18, $89081 \mathrm{Ulm}$, Germany
}

Correspondence should be addressed to Hasan Mahamudul; hasan_041097@yahoo.com

Received 29 December 2015; Accepted 26 April 2016

Academic Editor: Wilfried G. J. H. M. Van Sark

Copyright (C) 2016 Hasan Mahamudul et al. This is an open access article distributed under the Creative Commons Attribution License, which permits unrestricted use, distribution, and reproduction in any medium, provided the original work is properly cited.

\begin{abstract}
This work represents an effective design of a temperature regulated PV module by integrating phase change materials for Malaysian weather condition. Through the numerical analysis and experimental investigation it has been shown that if a PCM layer of width $0.02 \mathrm{~m}$ of RT 35 is used as a cooling arrangement with a PV module, the surface temperature of the module is reduced by $10^{\circ} \mathrm{C}$, which remains constant for a period of 4-6 hours. This reduction of temperature implies the increase in conversion efficiency of the module. Experiment as well as investigation has been carried out considering typical Malaysian weather. Obtained result has been validated by using experimental prototype and comparative analysis.
\end{abstract}

\section{Introduction}

The power generation of PV module is highly influenced by the temperature. Typical commercial silicon based cells convert only $10-20 \%$ of the incident light into electricity; the rest is transformed into heat, which causes a rise in temperature of the PV module. Such elevated operating temperatures are known to reduce the solar to electrical conversion efficiency making temperature a significant factor of consideration. To enhance the efficiency of the PV module it is important to keep the operating temperature as low as possible, preferably at the level of so-called standard test conditions (STC) or $25^{\circ} \mathrm{C}$ temperature with $1000 \mathrm{~W} / \mathrm{m}^{2}$ irradiation [1-10]. So, the efficient temperature regulation of $\mathrm{PV}$ modules can increase its efficiency by a significant level. Typically at high irradiance a PV temperature reduction of about $20^{\circ} \mathrm{C}$ is reported, which leads to a $9-12 \%$ increase in electrical yield depending on stratification. Hence, the application of phase change materials (PCM) can be a better solution for this purpose, because phase change materials have a high heat of fusion; they can absorb a lot of energy before melting or solidifying and the temperature remains constant during this phase transition. As a result when PCM is integrated with PV module due to the heat absorption property the temperature of the module remains at a constant level for this transition period. A number of works have been carried out throughout the few years related to this topic, but most of these are based on highly complicated numerical platform such as CFD, Multiphycis, and Energy plus [8-11]. But for this a work a comprehensive and simple numerical analysis has been carried out with MATLAB. The earlier works are mostly based on numerical analysis and have been carried out in European zone such as Ireland and Netherlands [1215]. But this experiment has been performed at Malaysian weather conditions and a complete experimental procedure has been explained with the numerical analysis.

\section{Complete System Overview}

The system mainly works based on the heat exchange properties of the phase change material and PV module. The excessive heat absorbed by the PV module is transferred to 


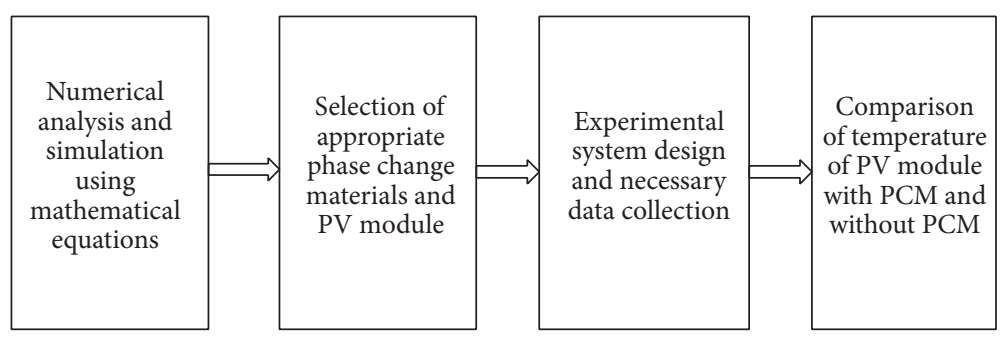

FIGURE 1: Flow chart of the complete work.

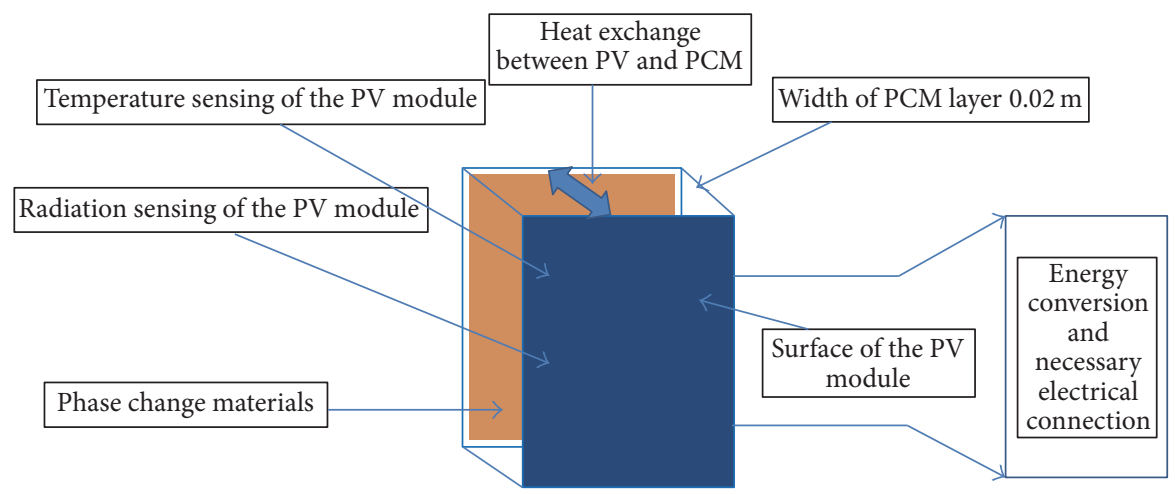

Figure 2: Schematic arrangement of the PV-PCM system.

phase change materials. When the temperature of the PV module reaches the melting point of the PCM, the operating temperature of the module gets stacked at that level and remains constant during the phase transition.

However, the complete work has been carried out according to the steps, which are shown in Figure 1.

After completing all the steps shown in Figure 1 the prototype was built. Figure 2 represents the schematic arrangement of the integrated PV-PCM system. Some issues should be considered at the time of designing the prototype as PCM should be melted on a nonsticky jar and poured on the rear part of the PV panel without affecting the electrical connection; while covering the panel with fiber-optic glass make sure that it has got a perfect insulation. Otherwise the phase change materials may leak at the liquid phase.

\section{Numerical Analysis of a PV-PCM System}

The thermophysical relationship between the PV module and phase change materials can be represented by the reference system of Figure 3.

According to the reference system the energy balancing equation of the PV-PCM system can be represented by the following equation $[1,12,15,18-23]$ :

$$
\begin{aligned}
C_{\mathrm{PV}} & \frac{d T_{\mathrm{PV}}}{d t}=\left[\text { Effective Irradiance }\left(I_{\text {reff }}\right)\right. \\
& - \text { Radiation }\left(Q_{R}\right)-\operatorname{Power}\left(P_{E}\right) \\
& - \text { Convection }\left(Q_{\mathrm{CV}}\right) \\
& \left.- \text { heat Stored by PCM plate }\left(Q_{H}\right)\right] .
\end{aligned}
$$

The difference between the input and output energy is equal to the rate of temperature change times to the specific heat capacity $\left(C_{\mathrm{PV}}\right)$ of the PV module. To calculate the temperature of PV-PCM system with respect to time, the value of $\left(d T_{\mathrm{PV}} / d t\right)$ has to be calculated from the above equation. This needs to calculate the terms of the right sides of the main equation, which can be found out by the following equations.

Effective irradiance can be calculated by

$$
\left(I_{\text {reff }}\right)=\phi \cdot \alpha \text {. }
$$

The radiated energy can be calculated the by Stefan-Boltzmann law, which states the relation between temperature and radiation as follows:

$$
\left(Q_{R}\right)=\varepsilon_{p} \cdot \sigma\left(T_{\mathrm{PV}}^{2}+T_{s}^{2}\right)\left(T_{\mathrm{PV}}+T_{s}\right) .
$$

$T_{s}$ is the sky temperature which can be calculated by modified Swinbank equation:

$$
T_{s}=0.037536 T_{\mathrm{amb}}^{1.5}+0.32 T_{\mathrm{amb}} .
$$

And the term electrical power depends on the insolation and temperature of the module and described by the following equation:

$$
\text { Power }\left(P_{E}\right)=C_{\mathrm{FF}} \cdot\left\{\frac{\phi \ln \left(K_{1} \phi\right)}{T_{\mathrm{PV}}}\right\} \text {. }
$$

The heat loss caused by convection can be defined as

$$
\begin{aligned}
& \text { Convection heat loss }\left(Q_{\mathrm{CV}}\right) \\
& =\left(h_{\text {front,natural }}+h_{\text {front,forced }}+h_{\text {rear }}\right) \cdot\left(T_{\mathrm{PV}}-T_{\mathrm{amb}}\right),
\end{aligned}
$$

where $h$ stands for the heat loss coefficients. 


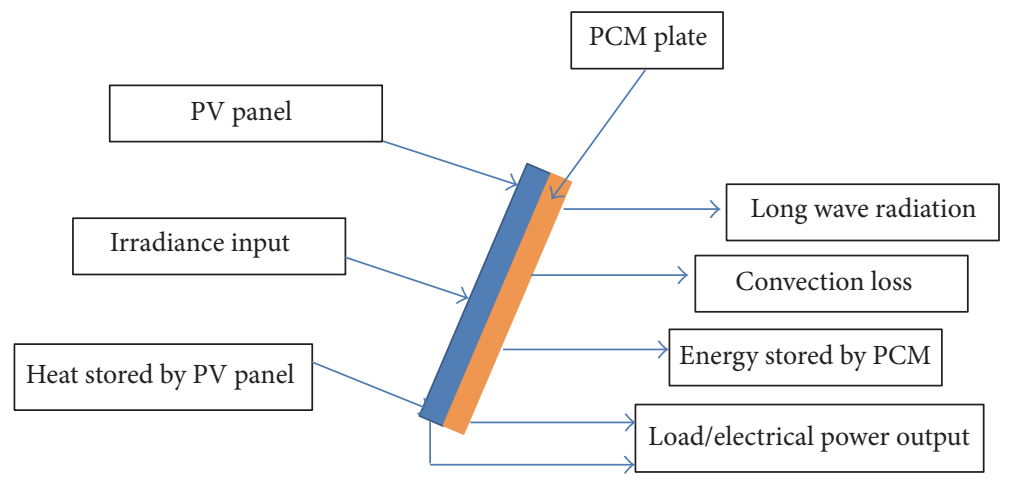

FIgURE 3: Thermodynamic reference model of PV-PCM system.

The necessary equation for the calculation of heat loss coefficient for the different parts of the PV module has been given below:

$$
\begin{aligned}
h_{\text {front,forced }} & =2.8+3.0 v ; \quad v \text { is the velocity of wind, } \\
h_{\text {front,natural }} & =1.78\left(T_{\mathrm{PV}}-T_{\mathrm{amb}}\right)^{1 / 3}, \\
h_{\text {front,total }} & =\left(h_{\text {forced }}^{3}+h_{\text {natural }}^{3}\right)^{1 / 3}, \\
h_{\text {rear }} & =1.31\left(T_{\mathrm{PV}}-T_{\mathrm{amb}}\right)^{1 / 3} .
\end{aligned}
$$

The energy stored by the phase change material is equal to the heat conduction that occurs from the PV panel to the PCM; it can be calculated by one-dimensional heat conduction method. The heat conduction from the PV panel to the phase change materials $\left(Q_{H}\right)$ can be calculated in three stages, which are

$$
\begin{array}{r}
\text { 1st stage Conduction } 1=K \cdot X\left(T_{\mathrm{PV}}-T_{\mathrm{amb}}\right) ; \\
T_{\mathrm{amb}}<T_{\mathrm{PV}}<T_{m},
\end{array}
$$

2nd stage Conduction $2=K \cdot X \cdot H\left(T_{\mathrm{PV}}-T_{m}\right)$;

$$
T_{m} \preceq T_{\mathrm{PV}} \sum_{i=0}^{n} K \cdot H \cdot S\left(T_{\mathrm{PV}}-T_{m}\right) \preceq H \cdot m,
$$

3rd stage Conduction $3=K \cdot X\left(T_{\mathrm{PV}}-T_{\mathrm{amb}}\right)$;

$$
\sum_{i=0}^{n} K \cdot H \cdot S\left(T_{\mathrm{PV}}-T_{m}\right) \geq H \cdot m .
$$

After combining all the terms of the reference equation (1), finally the expression for the rate of temperature change of the PV-PCM takes the form of

$$
\begin{aligned}
& \frac{d T_{\mathrm{PV}}}{d t} \\
& \quad=\frac{\left\{\phi \cdot \alpha+\sigma \varepsilon_{p}\left(T_{\mathrm{PV}}^{2}+T_{s}^{2}\right)\left(T_{\mathrm{PV}}+T_{s}\right)-C_{\mathrm{FF}} \cdot\left(\phi \ln \left(K_{1} \phi\right) / T_{\mathrm{PV}}\right)-\left(h_{\text {front,natural }}+h_{\text {front,force }}+h_{\text {rear }}\right) \cdot\left(T_{\mathrm{PV}}-T_{\mathrm{amb}}\right)\right\}}{C_{\mathrm{PV}}} \\
& \quad-\frac{\text { Conduction }}{C_{\mathrm{PCM}}} .
\end{aligned}
$$

However using the above equations the effect of phase change materials on temperature of PV system can be calculated by different numerical methods such as computational fluid dynamics (CFD), energy plus simulation platform, ANSYS, and MATLAB. However due to availability and versatile use aspects, MATLAB platform has been chosen for this work.

\section{Experimental Prototype in Lab Environment}

The most challenging part of this work is the development of experimental setup. In this work, an initial experimental prototype of PV-PCM system was built up in laboratory environment. The work has been completed in some steps such as melting of PCM, integrated with the rear part cooling of the PV-PCM system, covering the rear part with fiber optic glass, selection of position for taking temperature from the surface of module using movable thermocouple.

This experimental setup of the PV-PCM system was used to validate the output obtained from the numerical simulation. While designing the experimental prototype some points should be kept in mind as PCM should be melted with necessary precautions, after integrating PCM the rear part of PV module should be insulated properly, and most importantly the module's electrical terminal should 
Development of the complete experimental prototype

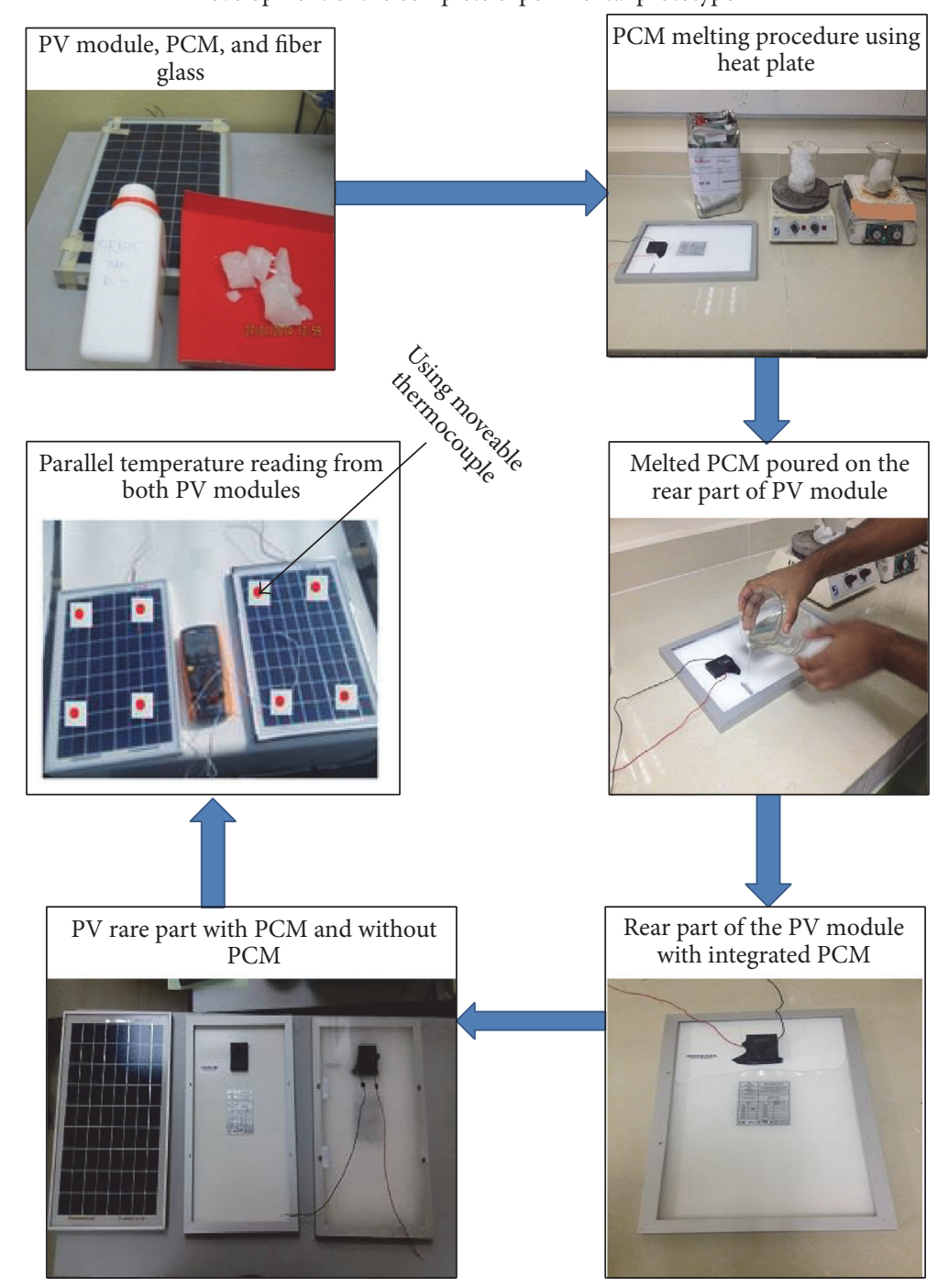

FIGURE 4: Development of the complete experimental prototype.

not be affected. However, Figure 4 represents the complete development procedure of the PV-PCM system for this experiment.

\section{Result and Discussion}

According to the numerical simulation the temperature output of the PCM integrated PV module with respect to different irradiations has been shown in the given figures.

Figure 5 shows that temperature of the PV module without $\mathrm{PCM}$ rises to $70^{\circ} \mathrm{C}$ at a constant radiation of $1000 \mathrm{~W} / \mathrm{m}^{2}$; when a PCM layer of RT 35 is integrated with the module, the temperature reduced to $35^{\circ} \mathrm{C}$ and it withstands for half of the simulation period, while the simulation has been carried out for $8000 \mathrm{~s}$ (second).

Similarly, Figure 6 shows that temperature of the PV module without $\mathrm{PCM}$ rises to $60^{\circ} \mathrm{C}$ at a constant radiation of $750 \mathrm{~W} / \mathrm{m}^{2}$; but after using the layer of phase change material
(RT 35), the temperature of the PV module reduces to $35^{\circ} \mathrm{C}$ and it remains constant for half of the simulation period.

Figures 5 and 6 represent the feasibility of using a PCM layer with a PV module to reduce the operating temperature of the complete system in numerical platform. However, to validate the numerical results, real-time experiment has been carried out on Malaysian weather.

Figure 7 shows the average radiation pattern of a Malaysian sunny day.

Figure 8 represents the temperature variation of a Malaysian sunny day.

At the above environmental conditions the experiment has been carried out and the obtained results are shown in Figure 9; the temperature of the PV module rises to $53^{\circ} \mathrm{C}$ without integrating phase change materials but the rise of temperature is limited to $42^{\circ} \mathrm{C}$ when a $0.02 \mathrm{~m}$ wide layer of PCM (RT 35) is used with the PV module.

From the figure it is also clear that the temperature of the $\mathrm{PV}$ module reduced by $10^{\circ} \mathrm{C}$ and it remains constant for a 


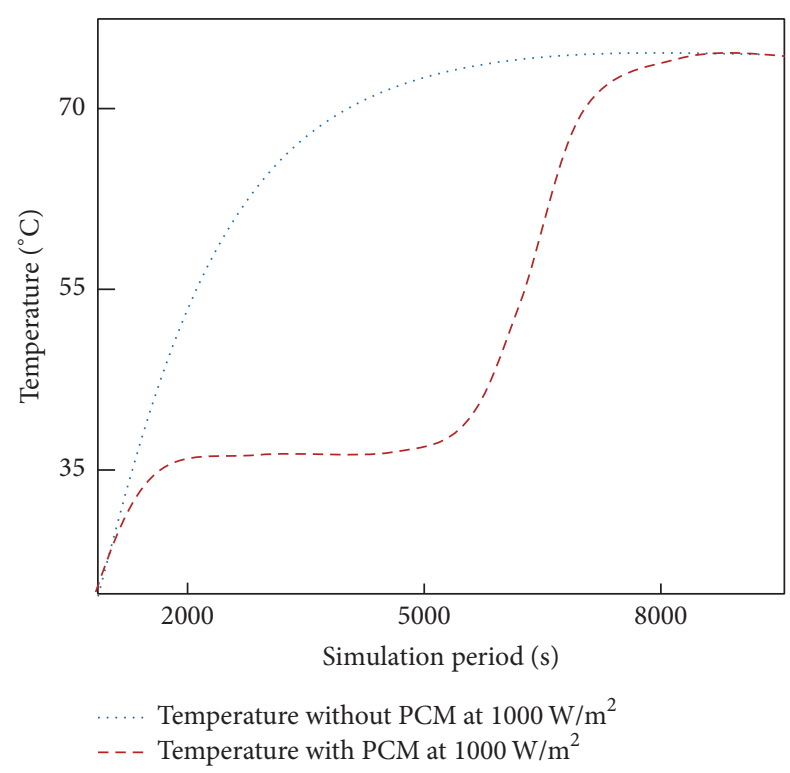

FIgURE 5: Temperature of PV module with PCM and without PCM at $1000 \mathrm{~W} / \mathrm{m}^{2}$.

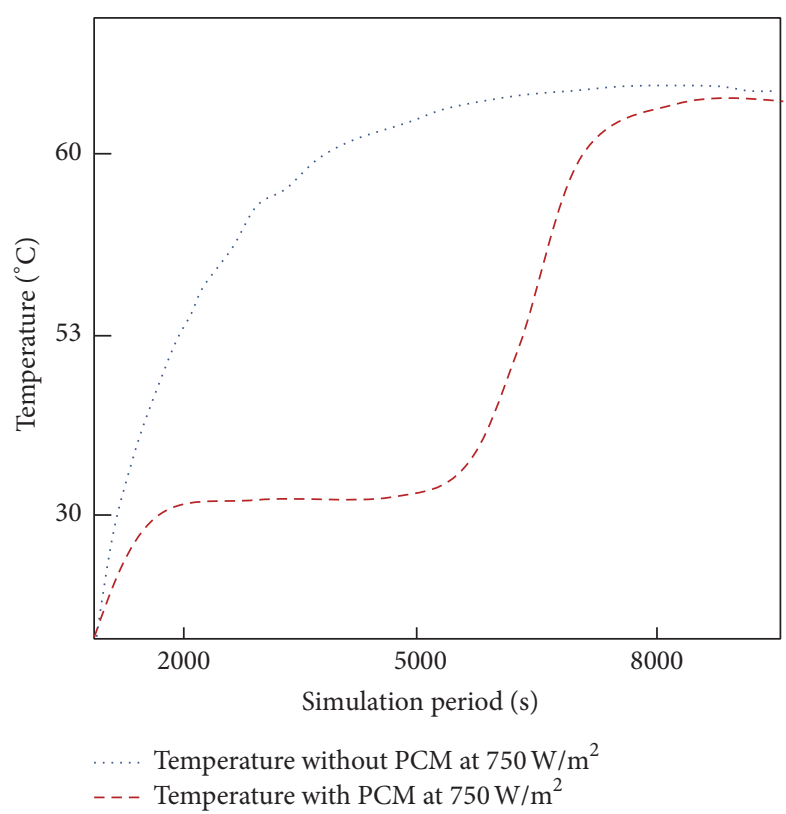

FIgURE 6: Temperature of PV module with PCM and without PCM at $750 \mathrm{~W} / \mathrm{m}^{2}$.

period of 5 hours (form 11.00 AM to 4.00 PM). So, numerical results and experimental investigation represent the validity of the developed system.

\section{Validation of the Result with Comparative Analysis}

Research in this field has been started by end of the previous decades in the cold European region. Especially in Ireland, Netherlands, and Germany a lot of people are working

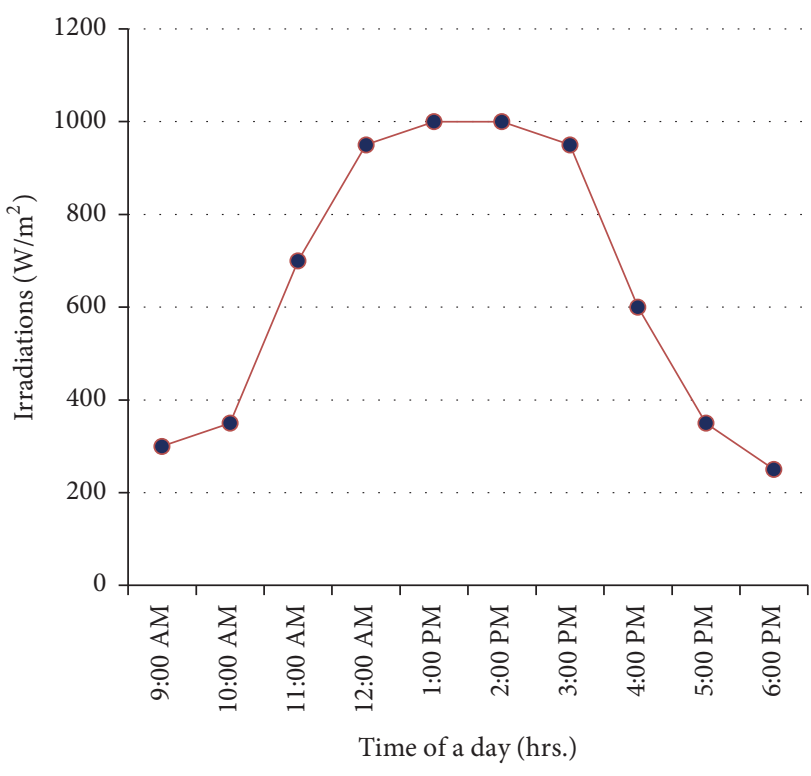

FIgURE 7: Radiation variation of a Malaysian sunny day.

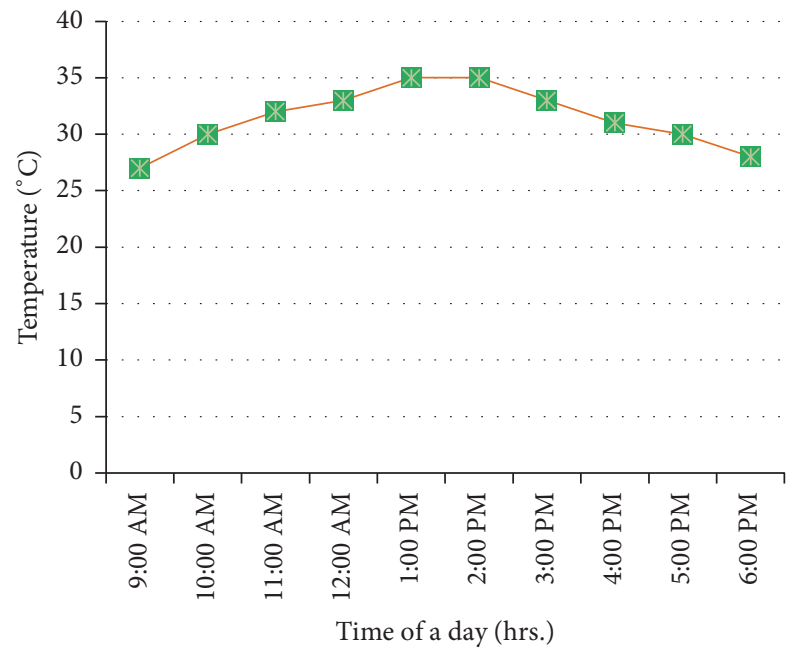

FIgURE 8: Daily temperature variation of a Malaysian sunny day.

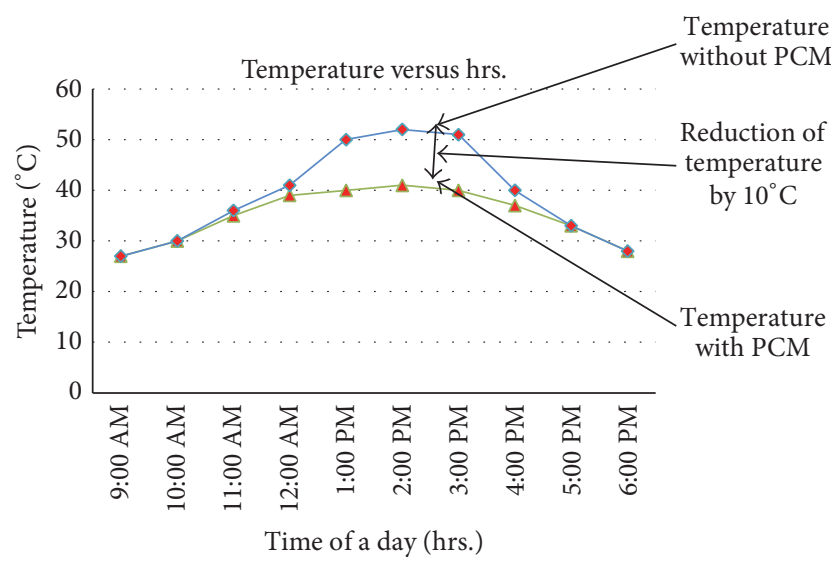

FIGURE 9: Experimental temperature variation of the PV module with PCM and without PCM. 


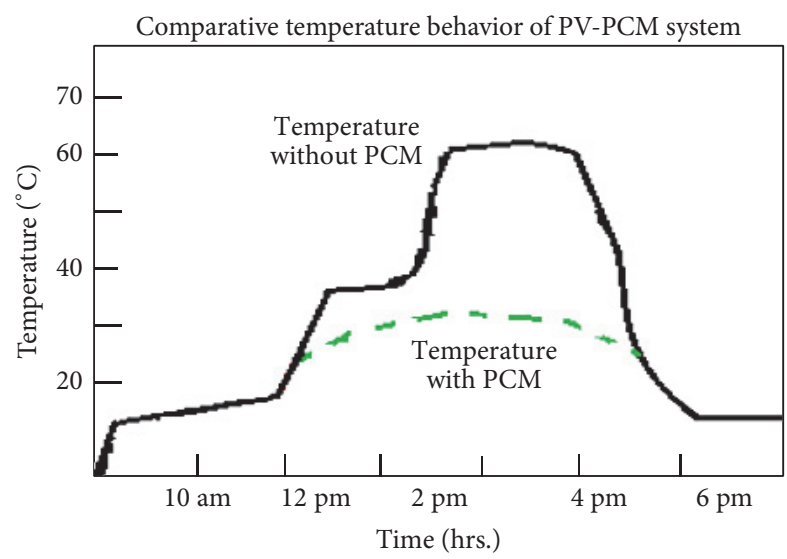

(a) PV-PCM temperature profile by Jun Huang in year 2011 [16]

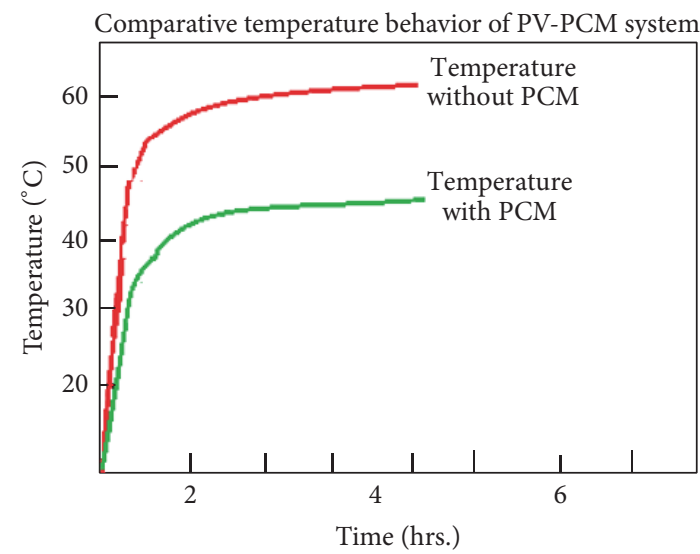

(b) PV-PCM temperature profile by Hendricks and Van Sark in year 2013 [11]

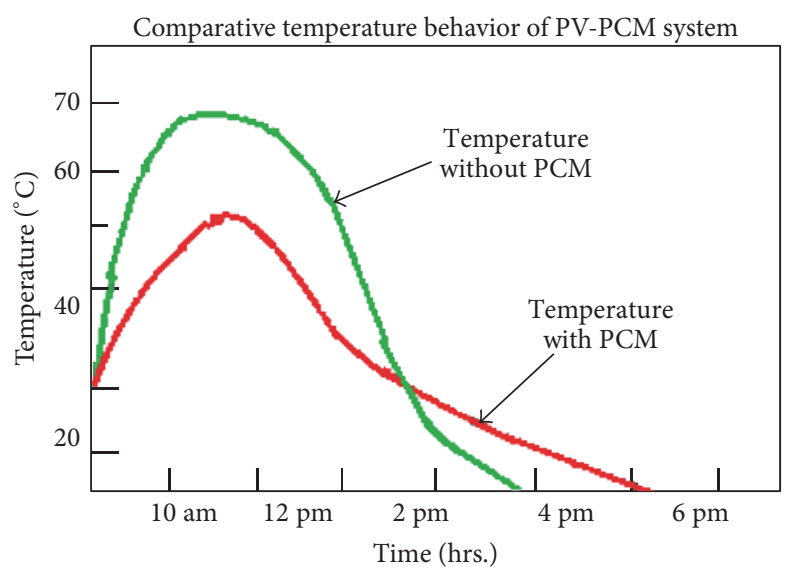

(c) PV-PCM temperature profile by Hasan et al. in year 2014 [17]

FIGURE 10: Comparative temperature profile of PV-PCM system obtained by different researchers.

TABLE 1: Comparative performance analysis of the PV-PCM system obtained by different researchers $[11,16,17,24]$.

\begin{tabular}{lccccc}
\hline Researchers & Used PCM & Temperature without PCM & $\begin{array}{c}\text { Temperature } \\
\text { with PCM }\end{array}$ & $\begin{array}{c}\text { Temperature } \\
\text { reduction }\end{array}$ & Constant temperature period \\
\hline Jun Huang [16] & RT-27 $7^{\circ} \mathrm{C}$ & $53-60^{\circ} \mathrm{C}$ & $35-40^{\circ} \mathrm{C}$ & $10^{\circ} \mathrm{C}-15^{\circ} \mathrm{C}$ & $4-6$ hours \\
Hendricks and Van Sark [11] & $\mathrm{RT}-27^{\circ} \mathrm{C}$ & $53-60^{\circ} \mathrm{C}$ & $35-40^{\circ} \mathrm{C}$ & $10^{\circ} \mathrm{C}-15^{\circ} \mathrm{C}$ & $4-6$ hours \\
Hasan et al. [17] & $\mathrm{RT}-22^{\circ} \mathrm{C}$ & $53-60^{\circ} \mathrm{C}$ & $30-35^{\circ} \mathrm{C}$ & $15^{\circ} \mathrm{C}-18^{\circ} \mathrm{C}$ & $4-6$ hours \\
Proposed system for Malaysia & $\mathrm{RT}-35^{\circ} \mathrm{C}$ & $53-60^{\circ} \mathrm{C}$ & $40-42^{\circ} \mathrm{C}$ & $10^{\circ} \mathrm{C}-12^{\circ} \mathrm{C}$ & $4-6$ hours \\
\hline
\end{tabular}

on these topics extensively. But the fundamental difference among their approach was the use of different types of phase change materials and main consideration behind this selection was the weather conditions. However, Figure 10 represents some recent and pioneer findings related to the work.

In Table 1 it is shown that the temperature profiles of PVPCM system obtained by different researchers from different regions of the world are quite similar to each other. In this respect, the findings of this paper obtained for Malaysian weather are also very close to the previous results, which ensure the validity of the developed PV-PCM module for Malaysian condition.

\section{Conclusion}

The numerical analysis and experiment output show that the application of phase change materials is able to regulate the temperature of PV module by $10^{\circ} \mathrm{C}$ for a period of around 6 hours at Malaysian weather. These reductions in operating temperature significantly enhance the conversion efficiency of PV module. So the fundamental objective of this work has been achieved. However, there occur some problems due to the issue of volume change of the PCM while integrating with PV module; if a shape stabilized phase change material can be used the problem will be solved. This will be the future step of this work. 


\section{Nomenclature}

\author{
$\phi$ : Total irradiance \\ $H$ : Heat storage capacity \\ $\alpha$ : The absorption constant \\ $m$ : The total mass of the phase change material \\ $\varepsilon_{p}$ : The emissivity of the module \\ $h$ : The heat loss coefficients \\ $\sigma: \quad$ The Boltzmann constant \\ $C_{\mathrm{PV}}$ : The specific heat capacity \\ $C_{\mathrm{FF}}$ : Fill factor which has a constant value $\left(1.22 \mathrm{~K} \mathrm{~m}^{2}\right)$ \\ $T_{s}$ : The sky temperature \\ $K_{1}$ : Constant with a value $\left(10^{6} \mathrm{~m} \mathrm{~W}^{-1}\right)$ \\ $Q_{\mathrm{CV}}$ : Convection loss \\ $K$ : The heat conductivity constant of the PCM \\ $P_{E}: \quad$ Electrical power output \\ $X$ : Width of the PCM plate \\ $T_{\mathrm{amb}}$ : Ambient temperature \\ $Q_{H}$ : Heat stored by PCM plate \\ $T_{\mathrm{PV}}$ : Temperature of the PV module.
}

\section{Competing Interests}

The authors declare no conflict of interests.

\section{Acknowledgments}

The authors wish to thank all the members of Renewable Energy Cluster of University of Malaya for their kind cooperation. This work is under an ongoing project of the University of Malaya (Project no.: UMRG project-RP039A15AE). Authors would like to thank the University of Malaya Research Grant Authority for their necessary economic support.

\section{References}

[1] M. J. Huang, P. C. Eames, and B. Norton, "Thermal regulation of building-integrated photovoltaics using phase change materials," International Journal of Heat and Mass Transfer, vol. 47, no. 12-13, pp. 2715-2733, 2004.

[2] M. J. Huang, P. C. Eames, and B. Norton, "An experimental study into the application of phase change materials to limit the temperature rise in build integrated photovoltaic systems," in Proceedings of the Renewable Energy in Maritime Island Climates,September, pp. 143-150, Belfast, UK, 2001.

[3] M. J. Huang, "The application of CFD to predict the thermal performance of phase change materials for the control of photovoltaic cell temperature in buildings," in Proceedings of the 6th World Renewable Energy Congress, pp. 2123-2126, Brighton, UK, July 2000.

[4] M. Cellura, G. Ciulla, V. Lo Brano, A. Marvuglia, and A. Orioli, "A photovoltaic panel coupled with a Phase Changing Material heat storage system in hot climates," in Proceedings of the 25th International Conference on Passive and Low Energy Architecture: Towards Zero Energy Building (PLEA '08), Dublin, Ireland, October 2008.

[5] A. Hasan, S. J. McCormack, M. J. Huang, and B. Norton, "Evaluation of phase change materials for thermal regulation enhancement of building integrated photovoltaics," Solar Energy, vol. 84, no. 9, pp. 1601-1612, 2010.
[6] J. Bony and S. Citherlet, "Numerical model and experimental validation of heat storage with phase change materials," Energy and Buildings, vol. 39, no. 10, pp. 1065-1072, 2007.

[7] P. Lamberg, R. Lehtiniemi, and A.-M. Henell, "Numerical and experimental investigation of melting and freezing processes in phase change material storage," International Journal of Thermal Sciences, vol. 43, no. 3, pp. 277-287, 2004.

[8] T. N. Anderson, M. Duke, G. L. Morrison, and J. K. Carson, "Performance of a building integrated photovoltaic/thermal (BIPVT) solar collector," Solar Energy, vol. 83, no. 4, pp. 445455, 2009.

[9] S. Krauter and R. Hanitsch, "Actual optical and thermal performance of PV-modules," Solar Energy Materials and Solar Cells, vol. 41-42, pp. 557-574, 1996.

[10] M. J. Huang, P. C. Eames, and B. Norton, "Comparison of a small-scale 3D PCM thermal control model with a validated 2D PCM thermal control model," Solar Energy Materials and Solar Cells, vol. 90, no. 13, pp. 1961-1972, 2006.

[11] J. H. C. Hendricks and W. G. J. H. M. van Sark, "Annual performance enhancement of building integrated photovoltaic modules by applying phase change materials," Progress in Photovoltaic Research Application, vol. 21, no. 4, pp. 620-630, 2013.

[12] X.-Q. Wang, C. Yap, and A. S. Mujumdar, "A parametric study of phase change material (PCM)-based heat sinks," International Journal of Thermal Sciences, vol. 47, no. 8, pp. 1055-1068, 2008.

[13] N. R. Vyshak and G. Jilani, "Numerical analysis of latent heat thermal energy storage system," Energy Conversion and Management, vol. 48, no. 7, pp. 2161-2168, 2007.

[14] C. Chen, H. Guo, Y. Liu, H. Yue, and C. Wang, "A new kind of phase change material (PCM) for energy-storing wallboard," Energy and Buildings, vol. 40, no. 5, pp. 882-890, 2008.

[15] M. Zukowski, "Mathematical modeling and numerical simulation of a short term thermal energy storage system using phase change material for heating applications," Energy Conversion and Management, vol. 48, no. 1, pp. 155-165, 2007.

[16] M. Jun Huang, "The effect of using two PCMs on the thermal regulation performance of BIPV systems," Solar Energy Materials and Solar Cells, vol. 95, no. 3, pp. 957-963, 2011.

[17] A. Hasan, S. J. McCormack, M. J. Huang, and B. Norton, "Energy and cost saving of a photovoltaic-phase change materials (PV-PCM) system through temperature regulation and performance enhancement of photovoltaics," Energies, vol. 7, no. 3, pp. 1318-1331, 2014.

[18] E. Skoplaki and J. A. Palyvos, "Operating temperature of photovoltaic modules: a survey of pertinent correlations," Renewable Energy, vol. 34, no. 1, pp. 23-29, 2009.

[19] M. M. Farid, A. M. Khudhair, S. A. K. Razack, and S. AlHallaj, "A review on phase change energy storage: materials and applications," Energy Conversion and Management, vol. 45, no. 9-10, pp. 1597-1615, 2004.

[20] E. Radziemska, "The effect of temperature on the power drop in crystalline silicon solar cells," Renewable Energy, vol. 28, no. 1, pp. 1-12, 2003.

[21] B. Zalba, J. M. Marín, L. F. Cabeza, and H. Mehling, "Review on thermal energy storage with phase change: materials, heat transfer analysis and applications," Applied Thermal Engineering, vol. 23, no. 3, pp. 251-283, 2003.

[22] S. D. Sharma, H. Kitano, and K. Sagara, "Phase change materials for low temperature solar thermal applications," Research Reports of the Faculty of Engineering, Mie Universityrsity, vol. 29, pp. 31-64, 2004. 
[23] M. Kenisarin and K. Mahkamov, "Solar energy storage using phase change materials," Renewable and Sustainable Energy Reviews, vol. 11, no. 9, pp. 1913-1965, 2007.

[24] A. Hassan, H. Nouman, A. Assi, and B. Norton, “Temperature regulation and thermal energy storage potential of phase change materials layer contained at the back of a building integrated photovoltaic panel," in Proceedings of the 30th International Plea Conference, pp. 16-18, CEPT University, 2014. 

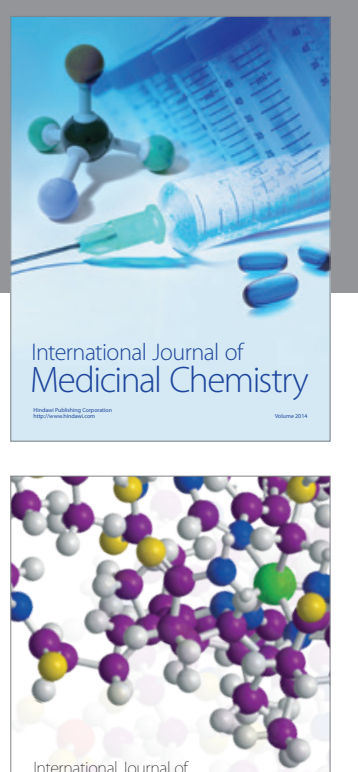

Carbohydrate Chemistry

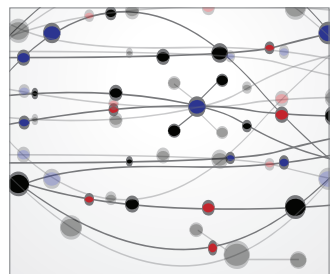

The Scientific World Journal
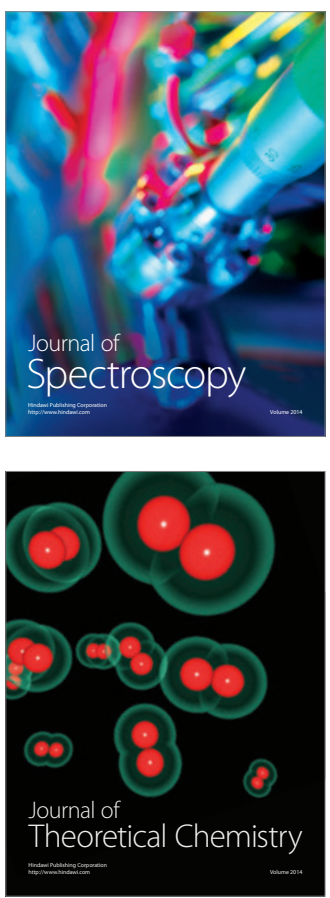
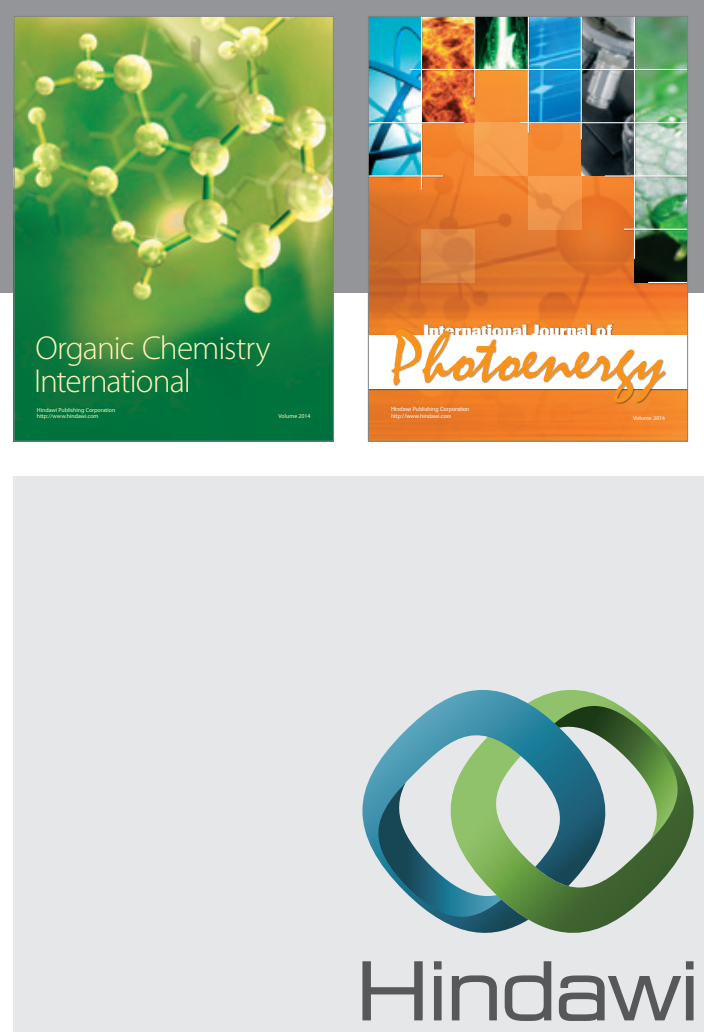

Submit your manuscripts at

http://www.hindawi.com

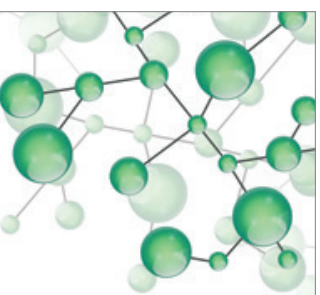

International Journal of

Inorganic Chemistry

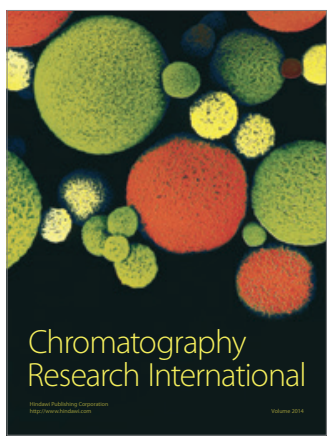

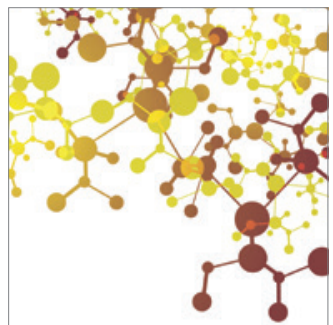

Applied Chemistry
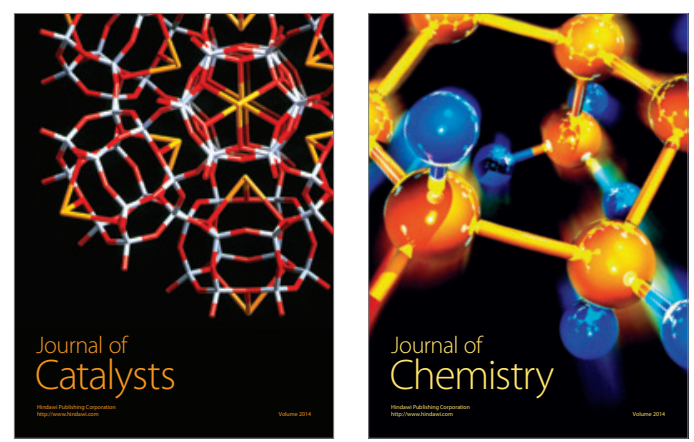
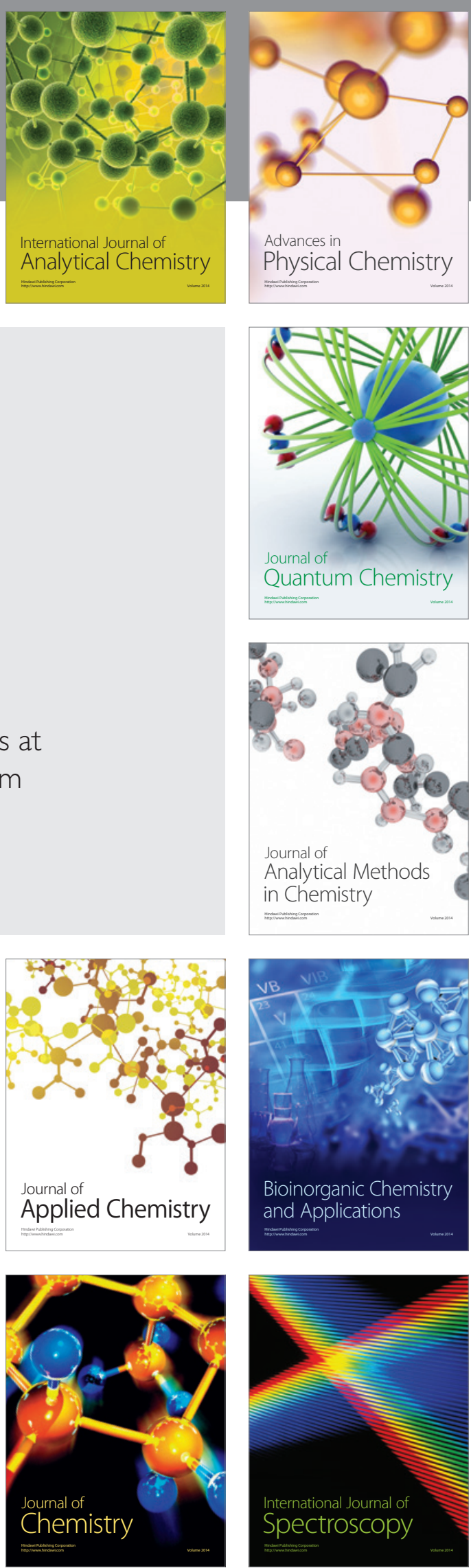